\title{
HIGHER EDUCATION GOVERNANCE OF MUSLIM MINORITY: EFFORTS TO BE PART OF NATION'S DEVELOPMENT
}

\author{
Ismail Suardi Wekke \\ Sekolah Tinggi Agama Islam Negeri Sorong \\ Jl. Klamono-Sorong, KM. 17, Klablim, Sorong, 98417 \\ E-mail:iswekke@gmail.com
}

\begin{tabular}{c|c|c}
\hline Received: & Revised: & $\begin{array}{c}\text { Approved: } \\
27 / 05 / 2018\end{array}$ \\
& $21 / 06 / 2018$ & $25 / 06 / 2018$ \\
\hline & \\
& (c) (†) (C)
\end{tabular}

Higher Education Governance Of Muslim Minority: Efforts To Be Part Of Nation's Development is licensed under a Creative Commons AttributionShareAlike 4.0 International License.

\begin{abstract}
The findings of this study may contribute to the government's efforts to tackle the terrorist movement in Indonesia. Education, until today, is believed to be one of the methods to conduct knowledge transformation. However, in the implementation of education, accessibility sometimes becomes one of the obstacles. Hence, this paper described several matters concerning the extension of access to education. This matter required a political policy concerning the availability of educational facilities. Set in West Papua Province, this study described higher education strengthening individual capacity. When an individual is capable and being empowered, it means that not only his/her family who enjoy that ability, but also the society and the nation will enjoy the advance and competitiveness of human resource excellence. This qualitative study also showed through data collection in descriptive way from observation during how limitations can be sources of strength. So the limitations need not be regarded as obstacles, but should even be opportunities to do innovations. The study also concluded how an unorganized higher education can have an impact on the economy
\end{abstract}


that will hamper the journey to seize the opportunity to know. Finally, with the reconstruction of various resources, universities can remain the best means of providing energy to serve civilization.

Keywords: Higher Education, Access, and Resources

\section{Abstrak}

Temuan penelitian ini berkontribusi terhadap upaya pemerintah dalam menanggulangi gerakan teroris di Indonesia. Pendidikan hingga hari ini diyakini sebagai sebuah metode untuk melakukan transformasi pengetahuan. Namun demikian, pada tataran implementasi, aksestabilitas pendidikan merupakan sebuah permasalahan tersendiri. Untuk itu, tulisan ini memberikan beberapa hal terkait dengan perluasan aksestabilitas pendidikan. Upaya perluasan harus ditopang oleh kebijakan politis terkait dengan ketersediaan fasilitas pendidikan. Studi yang dilakukan di Provinsi Papua Barat mendeskripsikan perguruan tinggi yang tengah memperkuat kapasitas individu civitas akademikanya. Manakala individu terberdayakan, tidak hanya keluarganya, tetapi masyarakat dan negaranya akan merasakan dampak positifnya. Penelitian kualitatif ini menggunakan data deskriptif dan observasi, penelitian juga menunjukkan bahwa keterbatasan aksestabilitas pendidikan adalah sumber kekuatan. Keterbatasan tersebut tidak pantas dipandang penghalang, melainkan sebagai tantangan untuk melakukan inovasi. Studi ini juga menyimpulkan bahwa sebuah perguruan tinggi yang kurang terorganisir memberikan dampak ekonomi yang menghalangi kesempatan untuk mendapatkan pengetahuan. Akhirnya, melalui rekonstruksi terhadap ragam sumber daya yang tersedia, perguruan tinggi diyakini tetap merupakan wahana penyedia energi positif bagi perkembangan peradaban.

Kata kunci: Perguruan Tinggi, Akses, dan Sumber Daya.

\section{A. Introduction}

Education serves as a strategic target. This is implicitly stated in the Special Autonomy Law of Papua and West Papua. So the attention of all layers of society is always questioning education as a primary requirement. To that end, the demand for increased educational capacity is always the desire of all parties. Moreover, education has become a means of generating skilled labors to 
promote the people welfare. These ideals become the framework for the continuity of education today. Not only to fulfill the mandate of the law, but more than that, it also to prepare educated personnel to become pioneers amid the community. As McCrea and Ehrich explained, adequate higher education can encourage the acceleration of community empowerment ${ }^{1}$.

The discourse on university of research has become part of the ideal purposes of higher education at this time, but this dream has not been reached for the region of Papua and West Papua. Currently, the most important and urgent is how to open the barriers so that the access to higher education is increasingly wide open. Once this agenda is over, the target that needs to be addressed is how to strengthen institutions will in turn have impacts on the strengthening capacity of the individuals involved. When this is achieved, the liberation of human beings from all bandages will be their own achievements and achievements. However, as long as education is not addressed, then backwardness will still be the reality of everyday life. This failure starts from the inability to form a scientific community in higher education².

The current agenda of the community of West Papua is how to provide adequate educational facilities in the sense of being able to reach, as well as providing the skills strengthening in accordance with the needs of the existing environment. A liberating prerequisite for education is where the education can be used as part of environmental adaptation. It is deemed a failure when education only meets the needs of science but not be able to free human beings from the shackles of nature. A greater mistake will be occurring when education is only taken as a tool of servitude towards fellow human beings. To fulfill the ideal purposes of education, all potential must be directed to explore and maximize the potential of humanity itself. With the use of

${ }^{1}$ Nadine Mccrea dan Lisa C. Ehrich, “Completing an Educational Leadership Picture: Feminine Essentials from an Australian Perspective," 25 Juni 2018.

${ }^{2}$ Heinke Roebken, "Similarity Attracts: An Analysis of Recruitment Decisions in Academia," Educational Management Administration $\mathcal{E}$ Leadership 38, no. 4 (1 Juli 2010): 472-86, https://doi.org/10.1177/1741143210368264. 
adequate technology, it is possible to implement educational processes that can accelerate community needs ${ }^{3}$.

If viewed from the perspective of the gap, higher education is only a higher level of education that already exists. Using this view, higher education should be able to include both basic and intermediate education already undertaken. The learning experience gained in school finds a place to be sharpened and developed in higher education. It is not something new at all, it should be able to be used to identify, summarize, and also utilize the learning experience as part of forming a scholar in the expert's sense. The next agenda is independence in academics ${ }^{4}$.

The urgent agenda for a university is how to optimize its resources. As small and limited as resources it has, it should be able to use them to get the main goal of education without waiting for having adequate resources in both quantity and quality. Soekartawi ${ }^{5}$ proposed to implement the strategy of "revitalization of university resources". Hence, this paper considers to reveals several matters concerning the extension of access to education in related to a political policy concerning the availability of educational facilities in West Papua

\section{B. Methodology}

This study employs a qualitative approach inline with various case studies and library research in the West Papua Province. This study selected this region due to its its characteristics with the encounter of Muslims and the Protestant community that met the established research criteria. Data collection was conducted for a year, from May 2016 to April 2017. The research was conducted in four stages: identification, data collection, data validity checking, and directed discussion. For data collection, observation and in-depth

${ }^{3}$ Anita L. Jetnikoff, "From Apprentice to Performer: Using Vodcasts to Bring English Teaching into the Tertiary Classroom," in Office of Education Research; Faculty of Education (30th HERDSA Annual Conference-Enhancing Higher Education, Theory and Scholarship, Adelaide, Australia: Higher Education Research and Development Society of Australasia (HERDSA), 2007), https://eprints.qut.edu.au/8995/.

${ }^{4}$ Aydin Balyer, "Academic Freedom: Perceptions of Academics in Turkey," Egitim ve Bilim 36 (1 Oktober 2011): 138-48.

5 Soekartawi, "Revitalisasi Sumber Daya Perguruan Tinggi untuk Meningkatkan Keunggulan Kompetitif" (Pertemuan Pimpinan Universitas Brawijaya, Malang, Agustus 2005). 
interviews were conducted with the research subjects in accordance with the criteria of the research problem. Interviews were conducted on several groups: lecturers, students, political elite and policy makers. All these were interviewed separately using the same question guides, while the observations were conducted six times with the same observation guidelines.

Furthermore, two-month extension of research was conducted in May and June 2017 to check again on two matters, they are, the condition of the Higher institutions in West Papua area that has the same criteria, and checks on the same research subjects in the in the same institutions. So it can be ascertained that the obtained data were valid data. The last part of the research carried out triangulation to check the validity of data through presentation and focus group discussions in STAIN Sorong in October $5^{\text {th }}$ 2017. All of them were conducted in order to ensure that research has explained the phenomenon in this study.

\section{Findings: Preliminary}

The role of higher education begins with optimizing existing resources. This is not due to lack of resources, but because it does not optimize what are owned and just craves what other institutions already have. To have a competitive ability, the solution that needs to be done from the beginning is the synergy between the various elements that exist. In today's demanding, the figure of a leader is no longer a foundation, but rather the strength of the team that is able to stimulate every individual to work with an orientation to maximum results.

The role of higher education with its three pillars has the power that is not owned by other institutions. The credibility of education, supported by its objectivity, is seen as a hope to bring this nation into a leading nation. The preceding explanation lays the foundation that there is hope to encourage people in Papua to move forward together. Therefore, this paper will explore and reveals its preliminary findings in some sections below, regarding to higher education as part of efforts to strengthen the capacity of the people of West Papua. 


\section{Leadership and Strategic Management}

True education is an important institution in the process of embedding values that will be useful in everyday life 6 . In the context of nation and state, the government has a position as a regulator for the society system and also in the formation of a permanent system as in education. An orderly education will have a positive impact in the form of educational advance with improved demographic structure. This will further achieve the quality of life affecting the development of various sectors. The key element of education lies in the government in the form of concern and seriousness to handle education. Thus, in the nations' education system, universities emerge from a long process. The skills, abilities and insights gained from primary to secondary education will gain legitimacy if they have been approved by higher education. Changes in the dynamics of society from time to time always demand the university to become a motor of transformation in the change itself. This sensitivity to change is manifested as a social responsibility for the establishment of a university for the community. The vision of the government is to take care of the needs of the community in the future ${ }^{7}$.

The opportunity to access education is the main objective of the government. Thus, there arises a policy regulating the obligation of a citizen to pursue an education which was previously only six years and then increased to be nine years, while the latest news says that it has reached twelfth year. This means that citizens in Indonesia, at least should complete an upper secondary school education. As a government obligation, at least twenty percent of the overall state budget is provided to serve as the cost of education. Any implemented program if not accompanied by two things: leadership power and strategic management formulation, will not reach maximal results. In conclusion, from other nations' experience, it has been proven that the existence of education governance will have an impact on

${ }^{6}$ Firdaus Firdaus, Faishal Yasin, dan Dian Kurnia Anggreta, "Penanaman Nilai-Nilai Multikulturalisme Melalui Pendidikan di Indonesia dan Malaysia," Open Science Framework, 7 Februari 2018, https:// doi.org/10.17605/OSF.IO/ A6QF7.

${ }^{7}$ Eddie Blass, Anne Jasman, dan Steve Shelley, “Visioning 2035: The future of the higher education sector in the UK," Futures 42 (1 Juni 2010): 445-53, https:/ / doi.org/10.1016/j.futures.2009.11.029. 
intelligence. If there is a group of intelligent citizens, then the welfare and competitiveness of the nation will be realized directly. The opportunity to play a role in education should also be interpreted as not merely a government affair but requires government leadership. To that end, the path to the availability of education should be prepared from the beginning.

If education is managed using the principle of leadership ${ }^{8}$, it will affect the nation's economic performance. Potentially, leaders must formulate and sell positive visions to their citizens for the sake of the community in the future. This is where leaders have to convince how the image of the future vision to the nation they lead. Failure to formulate this certainly plays a role to form a safe environment for the survival of a leader's political career and similarly of their groups. They should start with a vision of the future and then build an elite bureaucracy with staff with adequate managerial skills. Furthermore, although an authoritarian political system is established, there must be a supportive scope for the initiative of the policy in consultation. Finally, cooperation among the various elements in policy-making will shape organizational unity while avoiding the disintegration and lack of supports in the initiative and technical aspects. The enchantment of this relationship will present the power to realize a vision that is believed to be the hope of a large group in the future even though it originally started from just one's wish. The success of the top leadership in communicating his wishes will end in reality. Similarly, education must be oriented toward the future 9 .

If we want to generate outputs from researches that can encourage new discoveries, then a management that can encourage strategic research and development is needed. As information technology advances provide other services to support this industry, it means that the development of a technology is not only influential internally, but also has an indirect impact on other spheres of life. Another meaning is without the support of a conducive atmosphere,

${ }^{8}$ Mirwais Azizi, "Leaders of Higher Education in Afghanistan: Leadership Beliefs, and Challenges for the 21st Century" (Pepperdine University, 2008).

9 Marco Rieckmann, "Future-oriented higher education: Which key competencies should be fostered through university teaching and learning?," Futures 44 (1 Januari 2011): 127-35, https:// doi.org/10.1016/j.futures.2011.09.005. 
it will never be an innovation. Strategic management-oriented leadership will be the value driver (motor drive) to be the trigger to sustain the continuity of education. If it is failed to be realized, then procedurally could be a failure for the establishment of competitive advantages among institutions and at the same time will fail in the higher education competitiveness. But it does not stop there at the same time become a failure to become a nation's competitiveness power.

Beside vision, political power is also needed to be used to over come obstacles that hinder the goals to be achieved. The next thing to do is try to run the political choice maximally. The strengths and weaknesses of a policy are seen from its effectiveness in building an educational system. If the policy is set solely under compulsion, it might reflect the government's weakness. Then it might lead it to be a corrupt zone. If the bureaucracy cannot give proper service, then it could be a waste, an uncertainty, or a sloth in deciding a choice.

In addition, there is also a crucial aspect of political power in overcoming the obstacles. The next thing to do is try to run the political choice maximally. The strengths and weaknesses of a policy are seen from its effectiveness in building an educational system. If the policy is set solely under compulsion, it might reflect the government's weakness. Then it might lead it to be a corrupt zone. If the bureaucracy cannot give proper service, then it could be a waste, an uncertainty, or a sloth in deciding a choice. Such things will for sure distort the allocation of the resources. Of course, the people themselves will be lose. There will also be a concentration of unproductive wealth that, simultaneously, erode the noble culture, attitudes, and values that have been preserved from time to time. Without strong leadership, it will make the university structurally weak and unable to carry out the mandate. This is already showed in a Spanish university where the study conducted by Castro and Ion ${ }^{10}$ which the conclusion showed that some universities cannot run their autonomy mandates resulting from weak leadership they have.

${ }^{10}$ Diego Castro dan Georgeta Ion, "Government dilemmas in the Spanish universities: Autonomy, structure, participation and desconcentration," Revista de Educacion 355 (1 Mei 2011): 161-83. 
Changes exist. This function is believed by political practitioners who always work in an effort to build the nation's capabilities portfolio through education. There is a common environment in which competition occur. Social cohesion should serve as the foundation for further movement. Policymakers should not only focus on looking at educational factors solely but also synergizing other elements to collaborate within certain time frame. There are priorities needed to be executed at any given time. If the opportunity is failed to get, the opportunity will be gone. There is an opportunity that can become an effort to gain additional success. The opportunity is not solely in the competitive form, but in the highest value in accordance to the progress. In conclusion, there must be plans made to pursue the opportunity in promoting social development. Globalization gives us chance to work with other nations to optimize the utilization of the opportunity we will take. However, if the environment does not provide the chance to all of the processes, naturally it will become a loss of ability to utilize the existing value to serve as the foundation for further survival. The optimum environment will form the atmosphere for the development of performance as stated by Fernandez and Morales, Rodriguez, and Salmeron ${ }^{11}$ in their research which showed that universities with various variables elaboration are able to improve their performance from time to time.

Finally, choosing the right strategy is just as important as choosing the political action to take on the chosen strategy. Moreover, required superior quality bureaucracy that are able to run the decision maximally is also needed. Transformation is required from time to time. Gradually, there is an organizational transformation. The proper style of leadership which the political view is based on the strategy on rational politics. Of course, the good values, beliefs, and cultures formed also need direction of development that does not exploit all those resources for the sake of getting the progress, the intended direction will certainly be different. The discrepancy that is different from expectation keeps us away from the national expectations of health and education that merely serve as political tools. However,

${ }^{11}$ Antonio Fernández et al., "A System for Relevance Analysis of Performance Indicators in Higher Education Using Bayesian Networks," Knowledge and Information Systems 27, no. 3 (1 Juni 2011): 327-44, https://doi.org/10.1007/s10115-010-0297-9. 
both are not used to build a nation because of the productive workforce they have, but they have good talents and knowledge, that of course make the opportunity to utilize the human capital development will be a failure.

\section{Reality}

Nowadays, the roles of a university are shifting that it actually has already been going on in the last decade. Along with the reform, the environmental order of universities also changed. If so far the term Tri Dharma of Higher Education is "the holy book" for the higher education, it is necessary to make realization for the survival of the pillars in it. First, the pillar of education and teaching. If teaching is defined narrowly, it must be expanded with the educational process. Meetings with fifty minutes of each credit per semester may be enriched by the opportunity to process the information if every second was emerged through information technology instruments. The Lecturers are the educational facilitators, but they are no longer to be the only sources of information in teaching. Courses taught in the classroom can be complemented by the resources available through various channels. Information presented by the lecturers can be more complete if the students have the spirit of learning. It is not the problem of the sheer values, but the desire to increase the selfprofessionalism that matter.

The strength have by the students and lecturers is the idealism where not all parts of society are not in this circle. Science can be obtained from anywhere. Included with the development of community education, training institutions, and institutions that also encourage the mastery of skills. However, within the scope of idealism, only colleges that always have this characteristic. Thus, the shift in global dynamics is not an excuse to dilute this condition. Precisely, with the existence of the change, retaining pre-existing morale, and the morale itself are just as important as response toward the changes. The character of the nation is expected to be formed with the ongoing of the idealism. Moral and attitudes of the lecturers are expected to be taught to the students to form positive and creative attitudes to face the development. 
Second, the pillar of research. The word 'research' is often interchangable with the word 'study'. To support this pillar, the elements that must be exist is the desire to always question something and the creative attitude. If those two things do not exist, then the desire to advance research will stop. In the asspect of scholar, especially at the undergraduate level, not the one in vocational education, the ability needed is the ability to identify problems. A scholar is required to have problem-solving skill by using standardized scientific procedures. The power of analysis will in turn gain a high value in the objectivity and novelty of the research. This kind of activity will be a contribution to the progress of science. The classrooms will be richer with the research findings produced from the environment. Conversely, if only rely on what already exists, and the research results are taken for granted. This does not contribute to the scientific dialectics but demolish the existing scientific foundation. Therefore, it will cause stagnation, while the continuity of education is up to this pillar.

The research challenge is on its publication and utilization. The current researches, as well as the prerequisites for graduation at the educational level, did not take place optimally. The main constraint, in addition to the quality of the research, is not sufficient because it is not implemented seriously because of the lack of publication from existing research results. The study stopped in the examination room and library. Not published in reputable journals. Further, although the research is great it is only enjoyed among the limited community. Moreover, the government does not put any interest to utilize the research results in considering regulations. The disconnection between publication and utilization of researches is occur because they are not accompanied by good intentions and instead underlied by sectoral ego. However, undergraduate thesis research, not to mention the dissertation, spent energy and funds to be completed. Arranged undergraduate thesis neatly in the library is like piling up money and information generated from students, advisors, and examiners. Everything is wasted, because the researches are not going to be read and utilized.

Third, the pillar of community service. As how research becomes the structure for the higher education, with the establishment of Research Institutes or Research Centers, the community service 
which is facilitated by institutions that specifically take care of this community service is also important. University is not simply stop by educating and conducting research, then away from the reality of society. Precisely, the existence of the university is to encourage the existence of society to also take place dynamically. This purpose is implemented in the form of community service. Communities can be built with the view of experts who are directly involved in the present condition. Experts and students directly jump in to learn from the community. If, so far, it is only teachers or lecturers who take part in education, then by being in the community, every individual in the community can become a teacher or lecturer for university students.

In the last decade, since the reactivation of West Papua Province, the Human Development Index (HDI) has climbed to a higher level. It shifted up two positions from the previous one. This data showed that the increase in college contributes to the literacy rate in the region. In Sorong, the universities, both private and public, provide opportunity to students to choose various study programs (Prodi). Moreover, since 2010, the opening of the new study programs has reached to be double digits. By looking at the opportunities, the Ministry of Health established Sorong Health Polytechnic, the Teachers Training and Education of a Muhammadiyah College previously held a partnership class for Elementary School Teacher Education (PGSD), starting in 2013 the college has opened regular classes for the prodi. This means that the need of teachers as classroom teachers in primary schools can be obtained from the local graduates. So far, the elementary teachers in Papua were from the graduates from the universities outside Papua.

However, the enthusiasm of the university management is not accompanied by the government's primary policy. In this case, the Ministry of Education and Culture is authorized to manage the administration of higher education. The parameters used to grant operational permition to a college to open new study programs sometimes cannot be fulfilled administratively as how it is applied in other areas, while the local community need the study programs to be provided in their area. The available teachers are already able to carry out the classes that will be opened, but they still cannot achieve 
the indicators set by the government. In the meantime, there is no policy option to meet the existing needs. Therefore, in the practice, distance education is still implemented especially for post-graduate programs. The Magister classes are only held in three days a week, from Saturday to Sunday. It is usually attended by employees or workers. If it is investigated through the perspective of legislation and its derivative law, it will be considered as an aberration. It's just that on behalf of the need, then some community groups try to increase their knowledge by using shortcuts like this. Certainly, not justifiable, it should not be blamed entirely. It should also take into account the intricacies of educational administration that cannot be overcome.

The moratorium on the recruitment of civil servants that includes teachers and lecturers nationally harms the people of West Papua. The local schools still lacks of teachers. An islamic school in Tarof Village, Subdistrict of Kokoda, South Sorong District, has six classes that only taught by two teachers. Even, one of the teachers has been appointed to be the headmaster. The headmaster also sometimes served as the janitor who takes care of the keys and cleanliness of the school, while the other teacher is also in charge to be the treasurer to help manage the school's operational funds. With only two teachers since eight years ago and three years of moratorium, it is perfect for both teachers to take care of the six existing classes that change every year for eleven years. The central government policy that does not pay attention to the cases in the interior of West Papua. Not only in the interior, but also in the heart of Sorong where a state university stands with the name of Sekolah Tinggi (college). Since 2010, four programs have been added. The last lecturer's admission in 2010 only increased by five that the total lecturers teach in the college are sixteen. Four of the lecturers are continuing their study. With the addition of four study program, it makes the college to have seven study programs, the workload of the lecturers to teach has exceeded by twelve credits.

From this description, the expected maximum lecturing process cannot be fulfilled. The lecturers should also provide services to students, like being the head of departments, head of study programs, and the education administrations. The jobs should be done beside their main task to teach. They should also hold internal 
meetings and attend coordinations at a higher level. There are only 13 lecturers that serve the total of 500 students, so the opportunity to study in the classroom as one of the mechanisms to cultivate the interest of research does not take place maximally. If the lecturers are solely burdened with the task of teaching, the opportunities for conducting researches and doing community service will certainly reduce. By taking care of four different courses, the lecturers will be preoccupied with preparing teaching materials, assessing the process, evaluating, and completing other learning tools. There is no longer opportunity for them to compile textbooks. Sometimes, the lecture process is interrupted with meetings held in the state capital or elsewhere. Some lecturers are sometimes also asked to become the committees of the activities. Therefore, it is not odd if there are lecturers only give making papers assignments for certain courses for their students.

It is not rare that after the visitation of study programs in order to accreditation some lecturers who become the accreditation committee require a total rest for several days. Begin from the preparation of the forms, the physical evidence for the sake of visitation, until receiving the special assessors to verify everything written in the forms and so is the physical evidence to prove that the study programs have met the standards set by the government in the capital, Jakarta. There is a process that lasts for months, this takes time not only in working hours, but it is beyond that. At the same time, it also completed with the overtime working hours that have no consequence of anything in terms of finance. The willingness to do those jobs are driven solely by the desire to prepare the graduates to meet the administrative requirements. But, there should be concern and alignment from the accrediting party. If this is left unnoticed, the competence of the graduate will not change. Due to unqualified field conditions. But they are constructed in such a way to qualify. Then there is energy that is stacked there. Whereas the ideal ideals of accreditation in order to map the study programs to meet the needs of the community. The solution is expected, with the existence of such process, then the necessary steps of revamping are certainly needed. Not only by accrediting, but by placing learning as the process of intelligence. The Three Missions of Universities (Tri Dharma Perguruan 
Tinggi) guides demands to direct higher education as an instrument of community empowerment. But, if this is merely a slogan, then the public certainly cannot expect anything from all of this.

\section{Expanding Access to Encourage Competitiveness}

Based on the Rostow Model ${ }^{12}$ in higher education, there are five steps needed to be done to develop education in Papua. The key word from each of the steps is 'change'. First, traditional society. In educational activities, the traditional societies cannot use educational potential to disseminate the skills and abilities of educational graduates. A low level of literacy cannot drive them to get higher income. The economic exchanges that occur solely simply because of the government encouragement. The private sectors do not play significant roles in certain portions.

Second, the transitional society. There is a connection with other cultures. At the same time, the contacts, agreements of values, regional external assistance, and improvement of facilities are specifically identified as long-term capital and willingness to change. If there is no strong desire, then this is a vulnerable time where there will be a dominant influence of a particular group. At this stage, the need for physical and social infrastructure, although it is small, must be strategic. The educational change has been able to provide improvement for economic and social activities in society, but takes place on a limited scale.

Furthermore, the 'take off' community. This term was popular in the era of president Soeharto before it was plagued by the monetary crisis. If we are already in this stage, there is an accelerated rate in economic growth. To support expanding industries rapidly, the skilled personnel from educational institutions are formed in sufficient quantities to foster the industries. The desire to learn outside the area is also occured that give an opportunity to produce scientists to develop the region. Education is no longer purely theoretical, but the skills and creativity that are generated by the proves that the educated graduates are employed.

${ }^{12}$ W. W. Rostow dan Walt Whitman Rostow, The Stages of Economic Growth: A Non-Communist Manifesto (Cambridge University Press, 1990). 
The pillar next is technological maturity. In educational settings, high-technology and costly education will dominate the series and stages of education. Sufficient graduates' skills and technological skills that replace the workforce does not adapt itself to emerging technologies. The use of technology is then able to increase the work productivity and adequate wages for skilled workers. Productivity becomes a key word. Education then becomes an area to determine the use of technology. Since the beginning, the existence of technical aspects in educational units has been introduced. If it is supported by technology, education will open the ground for a bigger leap compared to the absence of technology in it. ${ }^{13}$

Lastly, high mass consumption pillar. As a result of per capita income that has exceeded basic needs, there is attention to quality of life. The issue of meeting the needs of clothes, food, and house is no longer important. On the contrary, how human existence makes life as an important instrument in society becomes a desire. Education is directed to be a humane education. Similarly, the competitive advantage of each graduate is formed. Not only the one who is able to master a particular field, but also specifically master the field is what make them very special.

Of those five stages, the key word of education is the management of education efficiently. It needs to be cultivated through the spirit of innovation by constantly learn the advantages and failures of each educational institution. Then, do the modification in accordance with the ability and existence of each environment. The utilization of existing educational resources supported by adequate technology will provide a competitive advantage not only in educational institutions but also for the alumni. Everything can be started by setting the institution's accountability, so that people's trust will arise. It includes autonomy, accreditation, and ongoing evaluation.

Furthermore, by recognizing the stages to be achieved, a strategy can be done to achieve the competitiveness by doing three things. First, establishing a major scientific competence. Scientific

${ }^{13}$ Alona Forkosh-Baruch dan Arnon Hershkovitz, "A Case Study of Israeli Higher-Education Institutes Sharing Scholarly Information with the Community via Social Networks," Internet and Higher Education 15, no. 1 (Januari 2012): 58-68, https://doi.org/10.1016/j.iheduc.2011.08.003. 
competence is characterized by three things: the wide access of potential resources, programs, and products. Second, the ability to increase the benefits of more to the users of college graduates. Third, having reliable ability, programs, and graduates that are difficult to compete by other college graduates. Thus, the college leaders and the subordinates should make the formulation of what will be produced after the process of constructing the educational experience. There must also be added value to be achieved by the graduates during the lectures. It is not limited to the scientific ability solely, but also supports for the continuity of life dynamics.

Second, the availability of self-evaluation that can be used for various purposes such as program planning and improvement of the educational process. Self-evaluation is a "portrait" of two things: progress and existence. With this portrait image, it will also be used in response to the present and future of the educational environment. This is related to the anticipation and response to the growing conditions. The word Late dose not exist. By being late, competitors are ready to take the leading position which is always the right of every institution.

Third, strategies and techniques to respond to global conditions. It starts from the introduction of the area. Further strengthening institutional capacity. The strengths of the institution are not limited solely to the internal environment but also the utilization of the external environment to support the internal existence. The ongoing competition has reached the hyper-competition according to Goldstein ${ }^{14}$. Goldstein's suggested prescriptions in addressing that atmosphere by doing several things, among others: strengthen the existing network of cooperation and then form a new alliance. Implement activities in order to transform the network into a partnership. The ability to use information technology. Finally, the efficient use of resources through the synergy of various activities is important.

Strengthening cooperation with both cognate and interdisciplinary institutions will support the teaching and learning

${ }^{14}$ M. Goldstein, “The Potential Competitive Advantage of Innovative for Profit/ Non-Profit Partnership in Higher Education" (Higher Education Consortium, n.d.). 
process. Similarly, joint research with outsourcing to provide research skills. The institutional network will also be able to support the improvement of institutional status, especially if the partner institution is an institution with the national and international reputations. The styles that can be developed by starting on a personal network (decision-making network) are then continued to the institution funding managers. This thrust will be sufficient if supported by the mastery and availability of information technology. The unity between networks, funding support, and technology management is able to strengthen institutions and will have an impact on the continuity of the universities. Including access to unrestricted financial resources in their own environment. ${ }^{15}$

A strategic partnership pattern between universities, communities, and industry will provide advantages for the universities through objectives and credibility. Student involvement in the programs implemented will bring sensitivity to the problems that exist in the community. The prominent value of such a program is the inclusion of students to gain experience as well as knowledge. For the institution, it will bring trust from people. For the industry, it can find a technology with the establishment of the synergy alike. A scientist who does not stand in the ivory tower but still rests on the realities of life of the people he inhabit will be born. At the same time, it is going to distance the universities from the alienation of the environment, but they have concerns for the community that become the study materials in the classrooms.

The important element in the formation of competitiveness as a major factor lies in human capital. The National assets are not important unless they are sustained by human resource reliability. If the level of knowledge and skills is higher, then there is convenience for the individual to understand the problem. At the level of understanding, they will be able to apply and get results for the technical progress. If this is optimally utilized, it will encourage the high standard of living. To obtain this, there must be an investment in education to build the education and skills system. The long-term educational development strategy will support the industrialization strategy gained from the

15 Elena Del Rey dan Maria Racionero, "Financing schemes for higher education," European Journal of Political Economy 26, no. 1 (2010): 104-13. 
skills of scientists and engineers. The investment of physical capital and national wealth will not mean anything if the productivity of human resources is reliable. The inability of investment, productivity, and production of goods are caused by the position of human capital in the form of skilled labor suppressing the level of industrial and technological development.

The source of the nation's wealth through competitiveness will be facilitated by adequate infrastructure. This can be achieved by creating infrastructure that supports subsequent economic expansion. While the developed countries, in a balanced state, is able to maintain the means of transportation, communication, and energy to be more advanced. This will stimulate the business investment, strengthen social infrastructure, and also increase physical capacity. Thus, the distinction is in educated personnel. With the inherited factors of educational availability from previous generations. The distinguishing factors will become more established if later generations are consisted of trained workers. Compared to the common factors, special factors form the basis for the determination and preservation of competitive advantage built on the common factors. The competitive quality in the aspect of quality and quantity once again determined the basis of social investment in education, including the government incentives in private education. ${ }^{16}$

\section{Theoretical Construction: Education for All}

Institutional strategic should be directed in a form that can be applied. The more pragmatic and concrete the identification of policies that will be pursued, the more helpful it is in realizing competitiveness. Mosley and Schmid mentioned two things to be considered: micro competitiveness and international competitiveness. Microcompetitiveness is a competitive advantage in the domestic sphere where the same universities are nationwide. Low cost of education, the attractiveness of the mastered, and the more lucrative scientific ecosystems compared to foreign competitors in the form of international universities. On the other hand, the international competitiveness is a comparative advantage. This factor is indicated

${ }^{16}$ Hasim Altan, "Energy Efficiency Interventions in UK Higher Education Institutions," Energy Policy 38, no. 12 (2010): 7722-31. 
by the ability to compete with international universities that have scope of fields. Not merely participating in the scientific environment, but producing leading researches to encourage further researches. As soon as universities conduct research, they will be marked by the acquisition of patents as a form of recognition in the applicative stage at the level of exact sciences.

To improve this, the main policy is needed, namely the primary policy that is regulated by the government. The second is a policy of government support to synergize the strategic stature to be achieved. For universities, the government needs to implement primary policies in the form of investment in the form of adequate infrastructure, industrial development strategies, and climate support for production publications. Whereas, in the case of supporting policy, it is important that the government's primary policy is efficient, such as the policies in macroeconomic, infrastructure development, and institutional framework development. Sufficient infrastructure in the form of physical, technological, human capital development, and development of small entrepreneurship will be great things for the development of higher education.

If universities are able to improve and better their environment, there is great hope to be continued for the survival of nation and state life. There are four things that can be done by the universities in order to sustain the nation's wealth-building strategy in the form of activities to assess the strengths and weaknesses of the state institutions, realizing dilemmas, trade-offs of policy options, building synergic relationships with good government, and enhancing cooperation with the government. The development of education requires the cooperation of the business world with the government. With adequate governance structures as well as involving forms of group representation, the same unity of purpose will be formed. If this can be achieved then it needs to be supported by strong leadership and charismatic, to bridge those two sectors in order to work together. Strong leadership will help higher education institutions with governance to address both internal and external issues. ${ }^{17}$

${ }^{17}$ Charles M Coco, "Emotional Intelligence in Higher Education: Strategic Implications for Academic Leaders - ProQuest," Journal of Higher Education Theory and Practice 11, no. 2 (2011): 112 - 117. 
The existence of educational institutions is intended to not only realize the "learning organization", but also the "learning nation". Porter originally introduced those terms which originated from the concept of "learning organization". The development of learning organization as a result of environmental development that sometimes experience turbulence and uncertainty. In the status of the learning organization, the university is required to form students and lecturers who always give creative ideas starting from the desire to know. However, this level continues to the state level with the term of learning nation. To form the nation's competitiveness, it requires creativity and continuous innovation. As a research that has cycles and procedures, the mastery of knowledge and economic ability is required nationally to create a learning nation environment. This could have been formed if there was consolidation of various elements of the nation to achieve these ideals. By continuing to learn, the nation always finds new information and also the development of the achievement of what already exists. Therefore, knowledge management is needed, where knowledge is managed by the principles of modern management. This effort is also applied in line with the orientation of social development on the empowerment of the community in building new social structures to restore or create a system that becomes the frame of reference in other social processes ${ }^{18}$.

Even if it only has knowledge, but does not have adequate governance, the existing resources will contribute nothing. With good management, a policy accompanied by wisdom will be made. As a long process, knowledge begins with gathering a series of question marks followed up with appropriate research designs to answer the curiosity. Processing information accurately accompanied by appropriate analysis will give meaning to an information. Without giving proper meaning and analysis, it will only be a set of data that cannot be a knowledge. Herein reflects the importance of human resources. With stretches of inaccessible areas and regions, one of the most viable options is to establish a distance learning network.

18 Firdaus Firdaus, "Evaluasi Proyek pembangunan Sosial Pada Kelompok Masyarakat Kawasan Hutan Mbeliling, Kab. Manggarai Barat, NTT,” Jurnal Ilmu Sosial Mamangan 5, no. 1 (26 Juni 2016): 13-22, https://doi.org/10.22202/mamangan.1926. 
Although not face-to-face, there is an ongoing educational process to ensure educational outcomes. ${ }^{19}$

For that reason, the reason for the territorial outreach will no longer be a reason for someone to not learn. The opportunity to learn should be open to anyone at all levels. Learning is the right of every individual, so that the state has an obligation to provide supporting facilities and infrastructure to facilitate every citizen in obtaining this right. The expansion of this opportunity should be a priority. ${ }^{20}$ Unless, after it is provided and there are citizens who choose not to get the right, it is entirely become an individual choice. But, on the side of the national community and the state, it becomes the mandate of the law to seek the availability of learning opportunities. The ultimate goals of all the process of independence with the establishment of the Republic of Indonesia is to educate every member of the state. It is the ideals that will be realized from the beginning that it has set forth in the preamble of the Constitution of the Republic of Indonesia. The state is obliged to prepare all the learning needs of its citizens. ${ }^{21}$

\section{Conclusion}

The demand for universities is already at a stage where the higher education must be the pioneer of transformation. It is not just the responsibility of the Three Missions of Universities (Tri Dharma Perguruan Tinggi) that must be enriched with innovation, but also to sharpen the sensitivity to take part in solving the problems that take place in society. It is not limited to the environment of the region, but to the national and even international stage. The demands that challenge the community of colleges are the role to participate in building civil society. In line with it, there is also a demand to produce a product that has the competitiveness and economic value for the

${ }^{19}$ Kwok Chi Ng dan David Murphy, "Evaluating interactivity and learning in computer conferencing using content analysis techniques," Distance Education 26, no. 1 (1 Januari 2005): 89-109, https:// doi.org/10.1080/01587910500081327.

${ }^{20}$ Elaine Keane, “Differential Prioritising: Orientations to Higher Education and Widening Participation," International Journal of Educational Research Complete, no. 53 (2012): 150-59, https://doi.org/10.1016/j.ijer.2012.03.005.

${ }^{21}$ Marann Byrne et al., "Motivations, expectations and preparedness for higher education: a study of accounting students in Ireland, the UK, Spain and Greece," Accounting Forum 36 (Juni 2012): 134-44, https://doi.org/10.1016/j. accfor.2011.12.001. 
community. Those ideals can be realized if they are brought together with continuous research activities. The absence of researches showed the absence of critical problems identification, as well as the innovation that has ceased altogether.

Universities also cannot escape from the economic development. The changes in global competitiveness are always accompanied by universities. Previously, the competitiveness was only in the aspects of wealth of natural resources and cheap low wages. Now, the era is over. The competitiveness to be demonstrated is in the aspects of innovation and creativity in terms of science, technology, and art. Tripartite cooperation between the higher education, industry, and government is needed to be more implementative and coordinated. If it refers to the experience that so far only done sporadically and temporary, it is not going to be profitable. Without it, the performance of universities will not reach the desired target. Although they have been done institutional restruction and administrative reform. Everything will be in vain.

Along with the advances of technology, the use of communication technology will help the learning process. The faster and massive development of information technology spread to and from different parts of the world, the more communities are connected to each other in various fields. ${ }^{22}$ This will encourage the mastery of adequate learning outcomes compared with other learning media. There is also efficiency both in terms of time and financing that can arise due to the use of communication technology in learning. In terms of time, there is an accelerated capacity increase and so does the productivity with the technology support. At the same time, the benefits of environmental conservation will be obtained by not using papers in terms of filing. The utilization of technology in education will also directly affect the better quality than ever. Such considerations will not only bring the need to maximize technology, including information technology, to produce quality researches, but also bring the impact of researches that can be gained by society[.]

${ }^{22}$ Nurudin Al Akbar, “'Menjinakkan' Globalisasi: Studi Kritis Globalisasi Budaya Pada Pementasan Sendratari Ramayana Borobudur," Jurnal Ilmu Sosial Mamangan 5, no. 1 (2016): 1-12. 


\section{REFERENCES}

Altan, Hasim. "Energy Efficiency Interventions in UK Higher Education Institutions." Energy Policy 38, no. 12 (2010): 7722- 31 .

Azizi, Mirwais. "Leaders of Higher Education in Afghanistan: Leadership Beliefs, and Challenges for the 21st Century." Dissertation, Pepperdine University, 2008.

Balyer, Aydin. "Academic Freedom: Perceptions of Academics in Turkey." Egitim ve Bilim 36 (1 Oktober 2011): 138-48.

Blass, Eddie, Anne Jasman, dan Steve Shelley. "Visioning 2035: The future of the higher education sector in the UK." Futures 42 (1 Juni 2010): 445-53. https://doi.org/10.1016/j. futures.2009.11.029.

Byrne, Marann, Barbara Flood, Trevor Hassall, John Joyce, Jose Luis Arquero Montano, Jose Maria Gonzalez Gonzalez, dan Eleni Tourna-Germanou. "Motivations, expectations and preparedness for higher education: a study of accounting students in Ireland, the UK, Spain and Greece." Accounting Forum 36 (Juni 2012): 134-44. https://doi.org/10.1016/j. accfor.2011.12.001.

Charles M Coco. "Emotional Intelligence in Higher Education: Strategic Implications for Academic Leaders - ProQuest." Journal of Higher Education Theory and Practice 11, no. 2 (2011): 112 - 117.

Del Rey, Elena, dan Maria Racionero. "Financing schemes for higher education." European Journal of Political Economy 26, no. 1 (2010): 104-13.

Fernández, Antonio, María Morales, Carmelo Rodríguez, dan Antonio Salmerón. "A System for Relevance Analysis of Performance Indicators in Higher Education Using Bayesian Networks." Knowledge and Information Systems 27, no. 3 (1 Juni 2011): 32744. https:// doi.org/10.1007/s10115-010-0297-9.

Firdaus, Firdaus, Faishal Yasin, dan Dian Kurnia Anggreta. "Penanaman Nilai-Nilai Multikulturalisme Melalui Pendidikan 
di Indonesia dan Malaysia." Open Science Framework, 7 Februari 2018. https:/ / doi.org/10.17605/OSF.IO/A6QF7.

Forkosh-Baruch, Alona, dan Arnon Hershkovitz. "A Case Study of Israeli Higher-Education Institutes Sharing Scholarly Information with the Community via Social Networks." Internet and Higher Education 15, no. 1 (Januari 2012): 58-68. https://doi.org/10.1016/j.iheduc.2011.08.003.

Jetnikoff, Anita L. "From Apprentice to Performer: Using Vodcasts to Bring English Teaching into the Tertiary Classroom." In Office of Education Research; Faculty of Education. Adelaide, Australia: Higher Education Research and Development Society of Australasia (HERDSA), 2007. https://eprints.qut. edu.au/8995/.

Keane, Elaine. "Differential Prioritising: Orientations to Higher Education and Widening Participation." International Journal of Educational Research Complete, no. 53 (2012): 150-59. https:/ / doi.org/10.1016/j.ijer.2012.03.005.

M. Goldstein. “The Potential Competitive Advantage of Innovative for Profit/Non-Profit Partnership in Higher Education." Higher Education Consortium, n.d.

Mccrea, Nadine, dan Lisa C. Ehrich. "Completing an Educational Leadership Picture: Feminine Essentials from an Australian Perspective," 25 Juni 2018.

$\mathrm{Ng}$, Kwok Chi, dan David Murphy. "Evaluating interactivity and learning in computer conferencing using content analysis techniques." Distance Education 26, no. 1 (1 Januari 2005): 89109. https:/ / doi.org/10.1080/01587910500081327.

Nurudin Al Akbar. “'Menjinakkan' Globalisasi: Studi Kritis Globalisasi Budaya Pada Pementasan Sendratari Ramayana Borobudur." Jurnal Ilmu Sosial Mamangan 5, no. 1 (2016): 1-12.

Rieckmann, Marco. "Future-oriented higher education: Which key competencies should be fostered through university teaching and learning?" Futures 44 (1 Januari 2011): 127-35. https:/ / doi. org/10.1016/j.futures.2011.09.005. 
Roebken, Heinke. "Similarity Attracts: An Analysis of Recruitment Decisions in Academia." Educational Management Administration $\mathcal{E}$ Leadership 38, no. 4 (1 Juli 2010): 472-86. https://doi. org/10.1177/1741143210368264.

Rostow, W. W., dan Walt Whitman Rostow. The Stages of Economic Growth: A Non-Communist Manifesto. Cambridge University Press, 1990.

Soekartawi. "Revitalisasi Sumber Daya Perguruan Tinggi untuk Meningkatkan Keunggulan Kompetitif." Makalah dipresentasikan pada Pertemuan Pimpinan Universitas Brawijaya, Malang, Agustus 2005. 